KENOSIS : JURNAL KAJIAN TEOLOGI

ISSN 2460-6901(Print), 2656-4483 (Online)

https://e-journal.iaknambon.ac.id/index.php/KNS

DOI: 10.37196/kenosis.v1i1.251

\title{
TINDAKAN KOMUNIKATIF BAGI ADI-KAKA: \\ Implikasi Pemikiran Jurgen Habermas Dalam Relasi Gandong Nusalaut Dan Ambalau
}

\section{Jovico Onis Samallo}

\author{
Universitas Kristen Satya Wacana \\ Jalan Diponegoro No.52-60, Salatiga, Kec. Sidorejo, \\ Kota Salatiga, Jawa Tengah 50711 \\ Vicojovico13@gmail.com
}

\begin{abstract}
This article aims to analyze inter-religious relationships based on the local wisdom of Gandong in Maluku, especially in the Nusalaut and Ambalau society as a strength in the modern era. It focuses on the social activities from the two communities as religious development in Maluku. The values of social activities become an inter-religious spirituality that is still passed down from generation to generation. Inter-religious relationships based on local wisdom (Gandong) from Nusalaut-Ambalau were analyzed using the communicative action theory approach by Jurgen Habermas. This article used a qualitative research method through interview technique, observation, and library study. Communicative actions have become an effort to maintain interreligious relationships in folklore. The increase folklore's imagination can be used by society as a preventive imagination on destructive realities.
\end{abstract}

Keywords: Local wisdom, gandong, Interreligious relationships, Communicative actions

\begin{abstract}
Abstrak
Tulisan ini bertujuan menganalisis hubungan antaragama yang berbasis pada kearifan lokal Gandong di Maluku, khusus pada masyarakat Nusalaut dan Ambalau sebagai sebuah kekuatan di era modern. Fokus pada aktivitas sosial berupa tindakan dari kedua masyarakat tersebut sebagai pengembangan beragama di Maluku. Nilai-nilai dari aktivitas sosial menjadi sebuah spiritualitas antaragama yang masih diwarisi turun-temurun dari generasi ke generasi berikut. Relasi antaragama yang berbasis pada kearifan lokal (Gandong) dari Nusalaut-Ambalau dianalisis menggunakan pendekatan teori tindakan komunikatif Jurgen Habermas. Penelitian ini menggunakan penelitian kualitatif - deskriptif dengan teknik wawancara dan studi pustaka. Tindakan komunikatif menjadi upaya menjaga relasi antaragama dalam folklor. Imajinasi
\end{abstract}


folklor yang berkembang dapat dijadikan oleh masyarakat sebagai imajinasi preventif pada realitas destruktif.

Kata Kunci: Kearifan lokal, Gandong, Hubungan antaragama, Tindakan komunikatif

\section{PENDAHULUAN}

Relasi antara masyarakat Nusalaut dan Ambalau merupakan hubungan antaragama dalam balutan kearifan lokal gandong yang pernah merasakan konflik 1999 di Maluku. Hubungan antaragama mengalami kesenjangan hingga konflik akibat masyarakat membatasi kehidupan dengan masyarakat yang lain, sehingga memengaruhi sikap yang lebih eksklusif dan pembenaran ajaran keagamaan dari masing-masing komunitas keagamaan. ${ }^{1}$ Dikarenakan individualisme masyarakat mengutamakan dogma agama dan tidak memperhatikan dogma dalam kehidupan sosial dan budaya. Tercatat dalam sejarah Indonesia, pada awal masa reformasi konflik atas nama agama terjadi di beberapa wilayah, semisal Ambon, Poso, dan Solo yang berdampak pada hubungan antaragama di wilayah tersebut. ${ }^{2}$ Konflik yang terjadi tahun 1999 di Maluku merupakan bagian dari politisasi agama di dalam konflik. Bukti dari politisasi agama dalam konflik Maluku dilihat pada durasi konflik sangat berkepanjangan dan meluas di beberapa wilayah di Maluku. ${ }^{3}$ Bagi masyarakat Maluku, di satu sisi, konflik 1999 telah menjadi sejarah kelam dalam perkembangan peradaban kebudayaan masyarakat. Namun di sisi lain, konflik tersebut menjadi sebuah pembelajaran dalam upaya mengembangkan pembangunan di Maluku, bahwa konflik hanya membuat masyarakat Maluku menderita akibat kehilangan harta dan nyawa. ${ }^{4}$ Kesadaran akan konflik membuat masyarakat (yang mengalami) trauma dengan konflik, sehingga adanya upaya untuk memulihkan ingatan-ingatan yang tersimpan dalam diri.

Pendekatan kearifan lokal pela dan gandong menjadi sebuah jalan untuk memulihkan ingatan-ingatan konflik yang tersimpan sebagai trauma. Kearifan lokal menjadi pegangan dalam kehidupan masyarakat Maluku sebagai ajaran dari para leluhur yang diwarisi sebagai kehidupan pluralis. Hal tersebut dijadikan sebagai kekuatan dalam kehidupan masyarakat, sehingga konflik yang terjadi dapat teratasi. 
Pela dan gandong memiliki esensi penting dalam menjunjung persaudaraan, saling membantu, dan saling menjaga relasi antar masyarakat di Maluku. ${ }^{5}$ Dengan kata lain, pendekatan pela dan gandong dapat menjadi nilai kemanusiaan yang menciptakan keharmonisan dalam kehidupan, bahkan implikasi pela dan gandong melampaui batas-batas keagamaan. Pela dan gandong digunakan sebagai sarana rekonsiliasi dalam masyarakat akibat terjadinya segregasi wilayah ketika konflik. ${ }^{6}$ Kekayaan lokal dalam masyarakat Maluku menjadi sebuah modal dalam upaya memulihkan ingatan konflik melalui perjumpaan antara komunitas Islam dan Kristen.

Sejauh ini, tulisan tentang relasi antaragama di Maluku berbasis kearifan lokal pela dan gandong telah menghiasi ruang akademik. Assagaf mengutarakan bahwa hubungan pela antara Negeri Batu Merah (Islam) dan Negeri Passo (Kristen) menciptakan suatu toleransi dalam beragama. ${ }^{7}$ Selain itu, Wakano mengungkapkan bahwa hubungan pela antara Negeri Batu Merah (Islam) dan Negeri Passo (Kristen) mengandung nilai-nilai pendidikan multikultural. ${ }^{8}$ Selain itu, Salakory mengutarakan bahwa hubungan pela gandong antara Negeri Wassu (Kristen), Negeri Haya (Islam), Negeri Hatu (Kristen) dan Tehua (Islam) memberikan rasa nyama saat konflik dan membangun rekonsiliasi pasca konflik. ${ }^{9}$ Realitas akademik, pela mendapat tempat terbanyak dibandingkan dengan gandong. Namun, perlu diketahui bahwa pela dan gandong memiliki pengertian dan historis yang berbeda dan hal ini kurang dipahami sebagai pengetahuan bersama. ${ }^{10}$ Perbedaan pengertian dan historis menjadi sebuah celah dalam melihat lebih dalam relasi antaragama berbasis kearifan lokal, khusus dalam hubungan gandong. Dalam realitas kemalukuan, masyarakat nusalaut dan masyarakat ambalau memiliki relasi gandong yang diimajinasi dalam folklor, serta implikasi sebagai kehidupan antaragama di Maluku. Untuk itu, titik fokus tulisan ini berpusat pada teori tindakan komunikatif Jurgen Habermas sebagai upaya menjaga kehidupan antaragama di Maluku dari realitas kehidupan masyarakat Nusalaut dan masyarakat Ambalau. Sebagai proses berteologi, kehidupan antaragama yang sejati memberikan ruang pada realitas budaya dan sosial berjalan bersama, sehingga norma kebudayaan yang menjadi turun-temurun dalam masyarakat terpelihara dengan baik.

Jurgen Habermas menyatakan bahwa tindakan komunikatif merupakan aktivitas dalam berkomunikasi yang memiliki orientasi semestinya dari realitas. Ada 
empat klaim yang digunakan berkaitan dan melengkapi satu dengan yang lain, pertama, klaim kebenaran, yaitu klaim yang berkaitan pada keobjektifan dunia alamiah. Kedua, klaim ketetapan, yaitu klaim tentang penerapan norma-norma sosial. Ketiga, klaim kejujuran, yaitu klaim tentang kesesuaian antara batin dan ekspresi. Keempat, klaim komprehensibilitas, yaitu klaim tentang kesepakatan, jika klaim kebenaran, klaim ketetapan dan klaim kejujuran terpenuhi sebagai alasan untuk konsensus. ${ }^{11}$ Dengan kata lain, tindakan komunikatif membutuhkan kesepakatan dalam setiap ruang perjumpaan antar individu dalam masyarakat. Dalam relasi antara, tindakan komunikatif dibutuhkan sebagai upaya menerima dan menghargai kehidupan sosial masyarakat.

\section{METODE PENELITIAN}

Dalam tulisan ini, penulis menggunakan metode kualitatif dan pendekatan deskriptif, dengan teknik pengumpulan data yaitu observasi, wawancara dan studi kepustakaan. Penggunaan metode kualitatif-deskriptif sangat membantu dalam proses mendapatkan data. Data dijadikan sebagai sumber untuk memahami fenomena. Data yang diperoleh dari hasil observasi, hasil wawancara dan studi kepustakaan menjadi pendukung penulisan.

\section{HASIL DAN PEMBAHASAN}

\section{Kearifan lokal gandong Nusalaut-Ambalau}

Pela dan gandong adalah suatu institusi kebudayaan yang mencerminkan hubungan persaudaraan, kekeluargaan dan kekerabatan pada masyarakat Maluku. Hubungan tersebut sangat dijaga oleh para leluhur melalui tindakan-tindakan saling menyayangi, tolong menolong (Masohi) dan keharmonisan, sehingga terciptanya kedamaian. Kearifan lokal pela dan gandong menjadi bagian integral dari interaksi sosial masyarakat Maluku. Relasi sosial masyarakat Maluku dibangun dan terbina dalam realitas kebudayaan yang mengedepankan penghargaan akan hak dan kewajiban yang sama dari interaksi sosial. ${ }^{12}$ Relasi sosial dalam kebudayaan masyarakat dapat menciptakan suasana keharmonisan dalam setiap proses realitas sosial masyarakat. 
Pada saat konflik melanda Kota Ambon, kearifan lokal pela dan gandong yang kuat dalam masyakarat Maluku, seketika mengalami kehilangan makna dan ritus. ${ }^{13}$ Saat itu, kota Ambon dihiasi kepulan asap, bunyi tembakan dan bom, serta isu dari orang-orang yang tidak bertanggung jawab. Isu agama dimainkan untuk melegalkan konflik yang menghancurkan peradaban masyarakat saat itu. Berkembangnya konflik di wilayah lain, semisal Seram, Halmahera, Kei, Lease dan Buru membuktikan masyarakat terhipnotis akan isu yang berkembang. Emosi yang sedang membara membuat masyarakat menjadi irasional dan melupakan warisan para leluhur yang sementara dijaga dari generasi ke generasi.

Berbicara tentang perdamaian pada saat konflik, menjadikan si pembicara dimusuhkan dalam komunitas tersebut. Ada upaya yang dilakukan untuk mencapai perdamaian, tetapi tidak sedikit mendapat pertentangan dari masyarakat. Gerakan perdamaian yang dilakukan mendapat pertentangan dari masyarakat, sehingga terkadang mereka dianggap sebagai penjilat oleh masyarakat. Bisa dikatakan hanya Tuhan dan nyanyian yang menjadi sarana penghibur ketika konflik terjadi. Namun, mendengarkan nyanyian gandong pada awal konflik membuat masyarakat menjadi marah, tetapi perlahan demi perlahan lagu tersebut diterima oleh masyarakat yang sadar akan kejadian konflik. ${ }^{14}$

Gandong la mari gandong, mari jua ale yo

Beta mau bilang ale, katong dua satu gandong

Hidop ade deng kaka, sungguh manis lawang $e$

Ale rasa, beta rasa, katong dua satu gandong

Gandong e, sio gandong $e$

Mari beta gendong, beta gendong ale jua

Katong dua Cuma satu gandong e

Satu hati, satu jantong e

Lagu Gandong yang populer bagi masyarakat Maluku dan Indonesia menjadi gambaran singkat dari hubungan persaudaraan di Maluku. Lagu gandong menceritakan tentang kekerabatan masyarakat Maluku, sekaligus meredamkan emosi pada saat konflik melanda Maluku. Lagu tersebut dinyanyikan pada saat konflik ibarat menaruh kepala di bilah parang (Pedang). ${ }^{15}$ Makna yang sangat kuat menjadikan lagu tersebut sebagai lagu kebangsaan (anthem) pada saat kumpul orang basudara (saudara 
berkumpul). Bukan hanya itu, lagu tersebut merupakan representasi dari memaknai identitas gandong di Maluku.

Gandong merupakan relasi persaudaraan berbasis pada hubungan darah antara dua negeri atau lebih. ${ }^{16}$ Gandong merupakan hubungan persaudaraan dari satu keturunan yang sama. ${ }^{17}$ Biasanya hubungan gandong tidak serta-merta hanya negeri yang memiliki kesamaan keagamaan, tetapi kebanyakan dialami pada negeri yang berbeda keagamaan, semisal Negeri Ouw (kristen) di Jazirah Tenggara Pulau Saparua dan Negeri Seith (Islam) di Jazirah Leihitu Pulau Ambon. Dalam perkembangan masyarakat, kesamaan dalam hubungan gandong membuat masyarakat hidup berdampingan, walaupun memiliki kepercayaan keagamaan yang berbeda. ${ }^{18}$ Hubungan gandong diwarisi turun-temurun oleh masyarakat mengalami sebuah nilai kekuatan antar masyarakat yang memiliki hubungan tersebut.

Relasi gandong dalam masyarakat Maluku bukan hanya antar negeri atau lebih, tetapi antar pulau, semisal Nusalaut dan Ambalau. Gandong menjadi diksi yang kuat akan makna, sebab masyarakat mempercayai bahwa para leluhur memiliki pertalian darah sebagai keluarga. Hal serupa terjadi pada masyarakat Nusalaut dan Ambalau yang dinarasikan dalam pengetahuan masyarakat (folklor). Relasi gandong dimaknai sebagai bentuk hubungan yang kekal dan tidak tergantikan dari generasi ke generasi berikut. Hal serupa pun dimaknai oleh masyarakat Nusalaut dan Ambalau yang memiliki hubungan gandong.

Nusalaut dan Ambalau merupakan hubungan gandong adi dan kaka yang terjadi di masa lalu. Folklor (cerita rakyat) Nusalaut-Ambalau berkembang dalam masyarakat dengan gambaran bahwa dulu kedua pulau ini merupakan sebuah dataran yang terhubung. Di dataran tersebut, hiduplah sebuah keluarga kecil yang memiliki dua anak. Pada suatu hari, sang kakak menemukan sebuah pohon sukung (Maluku: Sukun), tetapi sang adik pun mengingini pohon sukun kepunyaan kakaknya. Rasa mengingini tersebut membuat mereka berdua berkelahi dan tidak akur. Tiba-tiba pada suatu malam, dataran itu dilanda gempa dan mengakibatkan dataran itu terpisah menjadi dua. Sang adik hanyut dengan dataran yang terpisah (ambalau) meninggalkan kakaknya di dataran satunya (nusalaut). 
Hubungan gandong Nusalaut dan Ambalau tidak sebatas gagasan atau penggunaan semata, melainkan imajinasi yang terpatri dalam batin masyarakat. Terkadang sebuah gagasan dapat dipertentangkan ketika esensi sudah tidak sesuai tujuan dari gagasan tersebut. Namun, masyarakat Nusalaut dan masyarakat Ambalau tidak menjadikan hubungan gandong sekadar gagasan, tetapi imajinasi bersama dalam diri. Imajinasi yang terpatri telah menjadi bagian dari dalam hati dan maknanya melampaui gagasan atau istilah semata. Perjumpaan antara masyarakat Nusalaut dan Ambalau selalu dibawa ke ranah yang sempit yakni sebagai keluarga.

Sebagai satu keluarga, masyarakat Nusalaut dan Ambalau sangat menghindari narasi yang dapat memecahkan hubungan kedua masyarakat. Peristiwa yang terjadi di masa lalu bermakna agar jangan sampai terulang lagi di masa kini dan masa yang akan datang. Peristiwa terpisahnya Pulau Nusalaut dan Ambalau telah menjadi tanda erat hubungan kedua masyarakat. Keeratan hubungan masyarakat Nusalaut dibuktikan dari nilai-nilai persaudaraan yang telah menjadi warisan turun-temurun. Sikap menghargai dan menghormati dijadikan sebagai nilai persaudaraan yang tak lekang oleh waktu.

Bentuk sikap menghargai warisan para leluhur bukan hanya pada menuturkan folklor dari generasi ke generasi, tetapi sapaan adi-kaka sangat dijunjung. Masyarakat Nusalaut dianggap sebagai kaka (kakak), sedangkan, masyarakat ambalau dianggap sebagai adi (adik) berdasarkan tuturan cerita (folklor) leluhur. Sapaan adi-kaka bagi kedua masyarakat menjadi identitas dan menjadi konsensus bersama. Hasil konsensus dilihat dalam panggilan atau sapaan masyarakat Ambalau pada masyarakat Nusalaut sebagai kaka begitupun sebaliknya. Sapaan tersebut tidak memandang usia maupun status sosial, sehingga mempererat hubungan masyarakat Nusalaut dan masyarakat Ambalau.

Relasi masyarakat dengan latar belakang gandong berbeda dengan relasi masyarakat berlatarbelakang pela. Pela merupakan warisan dari masyarakat Maluku yang terwarisi dari generasi ke generasi berikut dan dipertahankan sebagai sebuah memori kolektif. ${ }^{19}$ Relasi pela dibangun oleh beberapa negeri didasari pada sebuah perjanjian yang disahkan melalui upacara sumpah (angka sumpah) oleh para leluhur saat itu. ${ }^{20}$ Biasanya dalam ritual angka sumpah para leluhur meminum darah, semisal hubungan pela ade-kaka antara Negeri Booi, Negeri Aboru, Negeri Kariuw dan 
Negeri Hualoy. Pela dan gandong memiliki esensi mempersatukan masyarakat Maluku sebagai sebuah komunitas yang tak terpisahkan. Namun menjadi pengetahuan bersama bahwa hubungan pela dimaknai sebagai media pemersatu hubungan antar negeri, tetapi pada esensinya, hubungan gandong melebihi ikatan hubungan pela. Dengan demikian, melalui hubungan gandong dapat dikatakan sebagai relasi masyarakat tertentu di Maluku yang memiliki garis keturunan dari hubungan sedarah para leluhur, tetapi perkembangan generasi ke generasi tidak menghilangkan esensi hubungan gandong.

\section{Hubungan gandong sebagai hubungan antaragama masyarakat Nusalaut dan Ambalau}

Di dalam realitas sosial masyarakat yang multikultural, agama menampilkan banyak cara sebagai kekuatan dalam upaya kemajuan peradaban. Di satu sisi, agama memberikan motivasi bagi masyarakat tentang persaudaraan, perdamaian, keselamatan, dan persatuan, tetapi di sisi lain agama diperalat dalam konflik. Tindakan keagamaan yang membuat dilema akan tantangan, menjadi sebuah tindakan sosial dari agama untuk bersikap fanatik dengan membenarkan agamanya. ${ }^{21}$ Hal-hal demikian cenderung menjadikan agama untuk tidak toleran dengan agama lain, sebab ketidaksepahaman akan kebenaran keagamaan, serta. dapat menjadi potensi konflik dalam masyarakat. Selain itu, kejadian-kejadian seperti ini berpotensi mengganggu hubungan antaragama di dalam realitas sosial masyarakat.

Dalam konteks sosial masyarakat Maluku, kearifan lokal seperti pela dan gandong menjadi sebuah modal sosial dalam setiap interaksi masyarakat Maluku. Pela dan gandong tidak sekadar menjadi gagasan dari pengetahuan masyarakat, tetapi menjadi pola tindakan sebagai sebuah warisan. Keadaan demikian terkadang membuat kearifan lokal dari masyarakat diimajinasikan masuk dalam setiap perubahan atau modernisasi. ${ }^{22}$ Dalam realitas sosial masyarakat, pela dan gandong dapat menciptakan keseimbangan dalam kehidupan masyarakat, serta menjaga dan mewarisi kebudayaan para leluhur. Kearifan lokal berfungsi sebagai pendorong dari terbangunnya kebersamaan, apresiasi dan mekanisme kolektif dalam upaya preventif kerusakan solidaritas masyarakat. ${ }^{23}$ Dengan kata lain, kearifan lokal dijadikan sebagai upaya pencegahan kehancuran tatanan sosial masyarakat yang terbangun dengan 
keharmonisan para leluhur, sekaligus menjaga dan merawat warisan leluhur turuntemurun.

Relasi antara masyarakat Nusalaut dan Ambalau dapat dikatakan bagian dari dialog antaragama berlatar belakang kearifan lokal yakni gandong. Menurut Lattu, studi intertekstual dapat digunakan sebagai sebuah dialog antaragama dalam pendekatan kebudayaan untuk membangun sebuah pemahaman dan tindakan bersama dari masyarakat. ${ }^{24}$ Dialog antaragama dapat digunakan sebagai upaya saling memahami perbedaan satu dengan yang lain dalam masyarakat beragama. Perjumpaan antara masyarakat Nusalaut yang berlatar belakang Kristen dan masyarakat Ambalau yang berlatar belakang Islam merupakan sebuah dialog antaragama dan dialog antar orang basudara. Hal tersebut menjadi sebuah keunikan tersendiri bagi masyarakat nusalaut dan masyarakat ambalau.

Dialog antaragama dapat dipahami sebagai komunikasi dua belah pihak atau lebih dari yang menyatakan pandangan mereka secara terbuka tanpa berapriori. ${ }^{25}$ Setiap pandangan yang keluar dari para pembicara menjadi pandangan baru yang memperkaya diri, sehingga pernyataan tersebut tidak dijadikan sebagai sebuah polemik. Pendekatan dialog antaragama sangat dibutuhkan kejujuran dalam upaya membangun kepercayaan dari para komunikan. Dialog antaragama menjadi cara efektif dalam menjawab persoalan bersama dalam kehidupan masyarakat dalam suatu keutuhan ciptaan. ${ }^{26}$ Kehadiran masyarakat Nusalaut dalam kehidupan masyarakat Ambalau dan sebaliknya telah mengalami penerimaan dari percakapan yang dibangun. Kerukunan adalah tujuan dari sebuah hubungan kekeluargaan yang menjunjung tinggi melalui budaya para leluhur melalui sikap saling menghormati dan menghargai dalam realitas sosial masyarakat Nusalaut dan Ambalau.

Dalam kamus besar bahasa Indonesia, kerukunan diartikan sebagai hidup bersama dengan perasaan rukun di dalam masyarakat. ${ }^{27}$ Kerukunan dimaknai sebagai sikap menjunjung kehidupan harmonis dengan menghargai setiap hidup manusia di dalam dunia. Kerukunan membuat masyarakat hidup dengan penuh rasa damai dan rasa nyaman, sebab situasi telah menyediakan rasa aman bagi masyarakat. Keadaan masyarakat yang penuh dengan kerukunan sering melahirkan sikap hidup toleransi dalam masyarakat dan berpengaruh pada segala bidang di dalam masyarakat. 
Toleransi merupakan bentuk hidup saling menghormati, saling menghargai dan menerima keberagaman akan kebudayaan masyarakat. ${ }^{28}$ Sikap toleransi menunjukkan bahwa diperlukan kerendahan hati untuk menerima sesuatu yang telah ada di dalam masyarakat sebagai sebuah pengetahuan dan kepercayaan demi kehidupan bersama.

Kerukunan beragama menjadi sebuah kewajiban moral maupun sosial dengan melakukan tindakan-tindakan toleransi dalam kehidupan bermasyarakat. Pemberian nilai-nilai dan kebiasaan melakukan tindakan rukun tersalurkan melalui pendidikan formal keagaman. Pendekatan pendidikan mampu mengajarkan nilai-nilai saling menghargai dan melindungi satu sama lain. ${ }^{29}$ Pendekatan pengajaran merupakan sebuah tindakan yang dapat dikatakan mudah dalam menyerap setiap narasi didikan. Masyarakat yang memiliki keunikan dalam pengetahuan lisan mampu memberikan nilai-nilai kerukunan sebagai bentuk tindakan preventif dari pengaruh intoleransi yang dapat menghancurkan peradaban masyarakat.

Dalam perkembangan dialog antaragama, terdapat tiga landasan, yakni landasan ekspresi kebudayaan, identitas keagamaan, semisal kitab keagamaan dan gerakan sosial dalam menanggapi problematika sosial. ${ }^{30}$ Dialog antaragama dapat dibangun dengan melibatkan kitab keagamaan sebagai identitas masyarakat beragama di dalam proses-proses dialog tersebut. Selain itu, perlu memasukan kebudayaan di dalam dialog antaragama sebagai bentuk mengekspresikan ciri masyarakat yang berbudaya. Dalam konteks Indonesia kebudayaan dan keagamaan telah menjadi identitas di dalam masyarakat dan dipegang dalam proses-proses bermasyarakat. Keagamaan mengalami perkembangan dalam masyarakat, tetapi kebudayaan telah lama berdiam sebagai sebuah identitas bagi masyarakat lokal.

Relasi antaragama antara masyarakat Nusalaut dan Ambalau pastinya tidak terlepas dari prinsip-prinsip keagamaan dan prinsip kebudayaan. Sebagai masyarakat beragama, ajaran keagamaan yang diimani menjadi sebuah pedoman kehidupan bagi masyarakat Nusalaut dan Ambalau. Ajaran keagamaan mengalami perjumpaan dalam setiap dialog yang dibangun ketika masyarakat Nusalaut dan Ambalau bertemu dalam sebuah ruang perjumpaan. Namun sebagai masyarakat berbudaya, prinsip-prinsip yang terwarisi dari generasi ke generasi dalam masyarakat telah menjadi sebuah pengetahuan bersama, semisal folklor dan gandong. Oleh karena itu, setiap 
perjumpaan antara masyarakat Nusalaut dan masyarakat Ambalau bukan serta-merta memegang prinsip keagamaan, tetapi prinsip kebudayaan mendapatkan sebuah nilai di dalam masyarakat Maluku.

\section{Tindakan komunikatif sebagai upaya berteologi}

Jurgen Habermas adalah seorang sosiolog Jerman dan menjadi generasi kedua dari Mazhab Frankfurt, serta menjadi penerus teori kritis dari generasi pertama. Teori kritis yang dicetuskan para Frankfurtian sebelum membuka seluruh ideologis dan irasionalisme yang menutup kebebasan dan kemurnian berpikir manusia. ${ }^{31}$ Habermas ikut berkontribusi memberikan sumbangsih sebagai generasi Frankfurt dengan konsep komunikasi di dalam teori kritis. Baginya, komunikasi menjadi solusi penting dalam menyelesaikan permasalahan dari teori kritis. ${ }^{32}$ Kesatuan hubungan antara teori dan praksis menjadi tradisi dari Frankfurtian. Kesadaran rasional menjadi landasan praksis, sebab rasio tidak hanya tampak dalam realitas, melainkan interaksi antar individu dalam masyarakat berinteraksi dengan bahasa sehari-hari. ${ }^{33}$ Rasio mampu menciptakan realitas yang belum pernah dihadirkan sebelum, sehingga dengan interaksi imajinasi antar individu dapat menciptakan realitas tersebut.

Habermas berpendapat bahwa rasionalitas tidak serta-merta dimiliki oleh pengetahuan tertentu, tetapi dengan rasionalitas, individu sebagai subjek dapat berbicara dan bertindak memperoleh dan menggunakan pengetahuan. ${ }^{34}$ Tindakan komunikatif merekonstruksi rasionalitas dengan menggunakan bahasa sebagai media untuk bertindak. Tindakan komunikatif sangat mengutamakan pemahaman bersama (common understanding) dengan menghindari egoistik. Dalam pertukaran ide, individu berusaha meyakinkan lawan bicara untuk mengubah argumentasinya dengan tujuan mencapai konsensus yang rasional. ${ }^{35}$ Diskursus terjadi bukan hanya menentukan sebuah argumentasi yang menjadi konsensus bersama, tetapi dirkusus dapat dijadikan sebagai ruang meng-counter imajinasi yang mengubah kebudayaan dalam masyarakat, salah satunya hubungan antaragama berbasis kearifan lokal.

Dalam mencapai sebuah konsensus dalam masyarakat, penggunaan klaim validitas digunakan dalam komunikasi realitas. Diskursus adalah rasionalitas sepanjang memenuhi tiga klaim validitas, antara lain pertama, kebenaran yaitu klaim yang berkaitan pada keobjektifan dunia alamiah. Kedua, klaim ketetapan, yaitu klaim 
tentang penerapan norma-norma sosial. Ketiga, klaim kejujuran, yaitu klaim tentang kesesuaian antara batin dan ekspresi. Keempat, klaim komprehensibilitas, yaitu klaim tentang kesepakatan, jika klaim kebenaran, klaim ketetapan dan klaim kejujuran terpenuhi sebagai alasan untuk konsensus. ${ }^{36}$ Dalam masyarakat Nusalaut dan Ambalau, pencapaian akan klaim validitas menjadi sebuah kekuatan antaragama berbasis kearifan lokal gandong.

Klaim kebenaran. Relasi antara masyarakat Nusalaut dan masyarakat Ambalau sama-sama menghormati nilai-nilai keagamaan dan menjunjung warisan kebudayaan turun-temurun, yakni folklor. Folklor menjadi imajinasi bersama antara masyarakat Nusalaut dan masyarakat Ambalau dari realitas leluhur saat itu. Imajinasi tersebut yang menggambarkan situasi dan relasi masa lampau dari para leluhur dan mempertahankannya hingga saat ini. Secara alamiah, relasi para leluhur di masa lampau hidup hingga sekarang melalui rasional yang tak terbantahkan. Untuk itu, folklor menjadi sebuah pengetahuan dan pemahaman bersama antara masyarakat Nusalaut dan Ambalau, sehingga dijadikan sebuah modal sosial dalam konteks kehidupan di Maluku.

Klaim ketetapan. Dalam hubungan Nusalaut dan masyarakat Ambalau sangat menjunjung norma-norma sosial yang menjadi warisan para leluhur, yakni sapaan adi (untuk masyarakat Ambalau) dan kaka (untuk masyarakat Nusalaut). Sapaan adi dan kaka menjadi khas dalam setiap perjumpaan antara Nusalaut dan Ambalau. Kekhasan itu dilihat ketika kakek yang berambut putih dari pulau Ambalau pun terkadang memanggil anak muda dari nusalaut sebagai sapaan kakak. ${ }^{37}$ Bagi sebagian masyarakat hal tersebut terkesan tidak etis dalam tatanan realitas sosial, tetapi itulah warisan para leluhur yang dihargai dan dihormati turun-temurun. Dalam perkembangan relasi sosial antara kedua masyarakat, lahirlah sapaan baru yang seperti kaka nona, kaka nyong, tua bagi masyarakat Nusalaut dan Ade nona, Ade nyong, bongso bagi masyarakat Nusalaut. Pastinya sapaan tersebut tidak mengurangi nilai kekeluargaan, kekerabatan dan keharmonisan antar kedua masyarakat tersebut.

Klaim kejujuran. Poin penting dari klaim kejujuran adalah keterbukaan untuk menerima individu lain melalui ketulusan dan kejujuran dalam berkomunikasi. Dalam masyarakat Nusalaut dan Ambalau keterbukaan menerima perbedaan keyakinan 
direspons baik oleh kedua masyarakat. Realitas sosial masyarakat sangat menyulitkan individu yang memiliki perbedaan (keyakinan) diterima dalam masyarakat. Imajinasi keagamaan yang sangat melekat dan begitu kuat dapat menciptakan sikap dan tindakan intoleransi dalam masyarakat. Bagi masyarakat Nusalaut dan masyarakat Ambalau, sangat menjunjung nilai kekerabatan dan kekeluargaan para leluhur dan tindakan tersebut menjadi sebuah spirit penerimaan dalam hubungan antaragama. Hari raya besar keagamaan menjadi ruang perjumpaan dan penerimaan, sehingga telah menjadi kebiasaan dari kedua masyarakat. ${ }^{38}$

\section{KESIMPULAN}

Kearifan lokal gandong antara Nusalaut dan Ambalau merupakan sebuah kekayaan turun-temurun di dalam kehidupan kedua masyarakat tersebut. Relasi gandong Nusalaut dan Ambalau dapat dijadikan sebuah relasi antaragama yang berlatarbelakang kebudayaan gandong. Relasi tersebut merupakan warisan turuntemurun dari para leluhur hingga sekarang dan telah terpatri menjadi identitas kedua masyarakat. Teori tindakan komunikatif habermas menjadi sebuah konsensus hubungan antaragama berbasis kearifan lokal gandong antara Nusalaut dan Ambalau. Klaim validitas dalam hubungan antaragama pada Nusalaut dan Ambalau menjadi modal sosial di Maluku. Klaim validitas dapat digunakan sebagai upaya menangkal tindakan-tindakan radikalisme dan intoleransi yang berkembang di Indonesia. Perjumpaan menjadi ruang penerimaan antara masyarakat Nusalaut dan Ambalau, sehingga dapat dimanfaatkan sebagai sebuah kekuatan dari realitas sosial.

\section{Endnotes:}

${ }^{1}$ Cherian George, Pelintiran Kebencian: Rekayasa Ketersinggungan Agama Dan Ancamannya Bagi Demokrasi (Jakarta: PUSAD Paramadina, 2017): 272.

2 Anas Aijudin, "Mengelola Pluralisme Melalui Dialog Antar Agama (Sebuah Tinjauan Teoritik)," Jurnal SMaRT Studi Masyarakat, Religi Dan Tradisi 3, no. 1 (2017): 119.

3 Margaretha Margawati, "Konflik Antara Agama Atau Politisasi Agama," Prosiding Simposium Internasional Jurnal Antropologi Indonesia 1 (2000): 517.

${ }^{4}$ Lih, https://regional.kompas.com/read/2020/01/19/18392561/21-tahun-konflik-maluku-dan-harapanmasyarakat?page=all

${ }^{5}$ Sharon Michelle O Pattiasina and Izak Y M Lattu, "PEREMPUAN DAN PERDAMAIAN Hubungan Islam-Kristen Dalam Liminalitas Simbolik Kain Gandong Di Maluku” 11, no. 2 (2018): 227. 
${ }^{6}$ Hendry Bakri, "Resolusi Konflik Melalui Pendekatan Kearifan Lokal Pela Gandong Di Kota Ambon," The POLITICS: Jurnal Magister Ilmu Politik Universitas Hasanuddin 1, no. 1 (2015): 52-53, http://journal.unhas.ac.id/index.php/politics/article/view/133/pdf.

${ }^{7}$ Y H Assagaf, "TOLERANSI BERAGAMA (KAJIAN STUDI BUDAYA PELA MASYARAKAT ADAT NEGRI BATU MERAH DAN NEGRI PASSO)," Dialektika, 2020, https://jurnal.iainambon.ac.id/index.php/DT/article/view/1231.

${ }^{8}$ Abidin Wakano, "Nilai-Nilai Pendidikan Multikultural Dalam Kearifan Lokal Masyarakat Maluku," Pendidikan Agama Islam 4 (2019): 26-43.

9 Dalam Jejaring et al., "Jurnal Antropologi: Isu-Isu Sosial Budaya |" 1, no. June (2020): 70-80.

${ }^{10}$ Jozef Hehanussa, "Pela Dan Gandong: Sebuah Model Untuk Kehidupan Bersama Dalam Konteks Pluralisme Agama Di Maluku," Gema Teologi Duta Wacana 33 (2009).

${ }^{11}$ Sandra Olifia and Radita Gora, "Membangun Paradigma Komunikasi Dalam Perspektif Habermas," Jurnal Ikom Usni Vol. 5 No. (2017): 80.

${ }^{12}$ Direktorat Jendral Kebudayaan Departemen Pendidikan Nasional, Lembaga Budaya Pela Dan Gandong Di Maluku: Latar Sejarah, Peranan Dan Fungsinya (Jakarta: Proyek pengembangan media kebudayaan direktorat jendral kebudayaan departemen pendidikan nasional RI, 2000): 1-2.

${ }^{13}$ Azis Tunny, "Jejak-jejak perjumpaan," dalam Carita Orang Basudara:Kisah-kisah Perdamaian Maluku, Carita Orang Basudara, n.d. (Jakarta: Pusad Paramadina, 2014): 114.

${ }^{14}$ Jacky Manuputty, "Titik-titik balik di jalan orang basudara," dalam Carita Orang Basudara: KisahKisah Perdamaian dari Maluku. (Jakarta: Pusad Paramadina, 2014): 143.

15 Jacky Manuputty, "Gandong'ee, mari manyanyi," dalam Carita Orang Basudara: Kisah-Kisah Perdamaian dari Maluku. (Jakarta: Pusad Paramadina, 2014): 358.

${ }^{16}$ Jacky Manuputty, Carita Orang Basudara: Kisah-kisah Perdamaian di Maluku: xii.

${ }^{17}$ A Watloly, Menggali Sejarah Dan Kearifan Lokal Maluku (Jakarta: Cahaya Pineleng, 2012):8.

${ }^{18}$ Wakano, "Nilai-Nilai Pendidikan Multikultural Dalam Kearifan Lokal Masyarakat Maluku.": 37.

${ }^{19}$ Izak Y. M. Lattu,"Culture and Christian-Muslim Dialogue in Moluccas-Indonesia," dalam Race Alan, ed., A Journal of Dialogue and Engagement, vol. 10 (London, 2012):46.

${ }^{20}$ Frans Thomas, "Wacana Tradisi Pela Dalam Masyarakat Ambon,” Bahasa Dan Seni 38 (2010): 167.

${ }^{21}$ Dadang Kahmad, Sosiologi Agama (Bandung: Rosdakarya, 2000):165.

${ }^{22}$ Mohammad Takdir, "Model-Model Kerukunan Umat Beragama Berbasis Local Wisdom: Potret Harmonisasi Kebhinekaan Di Nusa Tenggara Timur,” Tapis 1 (2017): 68.

${ }^{23}$ Joko Tri Haryanto, "Kearifan Lokal Pendukung Kerukunan Beragama Pada Komunitas Tengger Malang Jawa Timur,” Analisa 21 (2014): 202.

${ }^{24}$ Izak Y. M . Lattu, "Beyond Interreligious Dialogue: Oral-Based Interreligious Engagement in Indonesia," dalam Andre P. Giordan, Giuseppe and Lynch, ed., "Interreligious Dialogue: From Religion to Geopolitic," in Interreligious Dialogue: From Religion to Geopolitic (Boston: Brill, 2019): 71.

${ }^{25}$ Olaf Scumman, Some Reflection on The Meaning and Aims of Interfaith Dialogue in Dialogue and Beyond: Christians and Muslims, Together on the Way (Switzerland: The Luteran World Moderation, 2003): 13-14.

${ }^{26}$ Yusak B. Setyawan, "Encountering State Ideology: Reading the Bible from an Indonesian Postcolonial Perspective," in Colonial Contexts and Postcolonial Theologies: Storyweaving in the AsiaPasific (New York: Palgrave Macmillan, 2014): 104.

${ }^{27}$ Departemen Pendidikan dan Kebudayaan, Kamus Besar Bahasa Indonesia (Jakarta: Balai Pustaka, 1985):850.

${ }^{28}$ UNESCO APNIEVE, Belajar Untuk Hidup Bersama Dalam Damai Dan Harmoni (Jakarta: Kantor Prinsipal Unesco untuk kawasan Asia-Pasifik, Bangkok dan Universitas Pendidikan Indonesia, 2000): 154.

${ }^{29}$ Azyumardi Azra, Bingkai Teologi Kerukunan Hidup Antarumat Beragama: Perspektif Islam (Jakarta: Gunung Mulia, 2006):287-289.

${ }^{30}$ Giordan, Giuseppe and Lynch, "Interreligious Dialogue: From Religion to Geopolitic." :72

${ }^{31}$ Budi Hardiman, Kritik Ideologi (Yogyakarta: Kanisius, 2009): 33.

${ }^{32}$ Marthin Jay, Sejarah Mazhab Frankfurt: Imajinasi Dialektis Dalam Perkembangan Teori Kritis (Yogyakarta: Kreasi Wacana, 2009):57.

${ }^{33}$ Frans Magnis Suseno, Pijar-Pijar Filsafat (Yogyakarta: Kanisius, 2005):152-153. 


\footnotetext{
${ }^{34}$ Jurgen Habermas, Theory of Communicative Action: Reason Dan the Rasionalization of Society (Boston: Beacon Press, 1984): 11.

35 Tri Harnowo, "PENERAPAN TEORI DISKURSUS HABERMAS SEBAGAI ALTERNATIF PENYELESAIAN SENGKETA," Mimbar Hukum - Fakultas Hukum Universitas Gadjah Mada 32, no. 1 (2020): 66, https://doi.org/10.22146/jmh.45145.

${ }^{36}$ Olifia and Gora, "Membangun Paradigma Komunikasi Dalam Perspektif Habermas.": 80.

${ }^{37}$ Wawancara dengan Bapak N. Wairisal, tertanggal 29 Mei 2021. Dirinya (masyarakat yang berasal dari Nusalaut) menceritakan pengalaman Ketika bertemu dengan masyarakat dari Pulau Ambalau.

38 Wawancara dengan Bapak H. Lamia, tertanggal 23 Maret 2021. Narasumber menceritakan pengalaman ketika berkunjung pada hari raya lebaran di kediaman Masyarakat Ambalau.
}

\section{DAFTAR PUSTAKA}

Adriaansz, Sofia Liana, Izak Yohan Matriks Lattu, and Rama Tulus Pilakoannu. "Pela Bola: Modal Sosial Pela Yang Dibentuk Melalui Sepakbola Sebagai Kekuatan Dalam Hubungan Islam-Kristen Di Maluku.” Humanika 26, no. 2 (2019): 49. https://doi.org/10.14710/humanika.v26i2.24496.

Alan, Race, ed. A Journal of Dialogue and Engagement. Vol. 10. London, 2012.

Anas Aijudin. "Mengelola Pluralisme Melalui Dialog Antar Agama (Sebuah Tinjauan Teoritik).” Jurnal SMaRT Studi Masyarakat, Religi Dan Tradisi 3, no. 1 (2017): 119-24.

APNIEVE, UNESCO. Belajar Untuk Hidup Bersama Dalam Damai Dan Harmoni.

Jakarta: Kantor Prinsipal Unesco untuk kawasan Asia-Pasifik, Bangkok dan Universitas Pendidikan Indonesia, 2000.

Assagaf, Y H. "TOLERANSI BERAGAMA (KAJIAN STUDI BUDAYA PELA MASYARAKAT ADAT NEGRI BATU MERAH DAN NEGRI PASSO).” Dialektika, 2020.

https://jurnal.iainambon.ac.id/index.php/DT/article/view/1231.

Azra, Azyumardi. Bingkai Teologi Kerukunan Hidup Antarumat Beragama: Perspektif Islam. Jakarta: Gunung Mulia, 2006.

Bakri, Hendry. "Resolusi Konflik Melalui Pendekatan Kearifan Lokal Pela Gandong Di Kota Ambon." The POLITICS : Jurnal Magister Ilmu Politik Universitas $\begin{array}{lllll}\text { Hasanuddin } & 1, & \text { no. } & 1 & \text { (2015): }\end{array}$ http://journal.unhas.ac.id/index.php/politics/article/view/133/pdf. 
TINDAKAN KOMUNIKATIF BAGI ADI-KAKA: Implikasi Pemikiran Jurgen Habermas Dalam Relasi Gandong Nusalaut Dan Ambalau

Departemen Pendidikan dan Kebudayaan. Kamus Besar Bahasa Indonesia. Jakarta: Balai Pustaka, 1985.

Direktorat Jendral Kebudayaan Departemen Pendidikan Nasional. Lembaga Budaya Pela Dan Gandong Di Maluku: Latar Sejarah, Peranan Dan Fungsinya. Jakarta: Proyek pengembangan media kebudayaan direktorat jendral kebudayaan departemen pendidikan nasional RI, 2000.

George, Cherian. Pelintiran Kebencian: Rekayasa Ketersinggungan Agama Dan Ancamannya Bagi Demokrasi. Jakarta: PUSAD Paramadina, 2017.

Giordan, Giuseppe and Lynch, Andre P., ed. "Interreligious Dialogue: From Religion to Geopolitic." In Interreligious Dialogue: From Religion to Geopolitic. Boston: Brill, 2019.

Habermas, Jurgen. Theory of Communicative Action: Reason Dan the Rasionalization of Society. Boston: Beacon Press, 1984.

Hardiman, Budi. Kritik Ideologi. Yogyakarta: Kanisius, 2009.

Harnowo, Tri. "PENERAPAN TEORI DISKURSUS HABERMAS SEBAGAI ALTERNATIF PENYELESAIAN SENGKETA.” Mimbar Hukum - Fakultas Hukum Universitas Gadjah Mada 32, no. 1 (2020): 55. https://doi.org/10.22146/jmh.45145.

Haryanto, Joko Tri. "Kearifan Lokal Pendukung Kerukunan Beragama Pada Komunitas Tengger Malang Jawa Timur.” Analisa 21 (2014): 201-13.

Hehanussa, Jozef. "Pela Dan Gandong: Sebuah Model Untuk Kehidupan Bersama Dalam Konteks Pluralisme Agama Di Maluku." Gema Teologi Duta Wacana 33 (2009).

Jay, Marthin. Sejarah Mazhab Frankfurt: Imajinasi Dialektis Dalam Perkembangan Teori Kritis. Yogyakarta: Kreasi Wacana, 2009.

Jejaring, Dalam, Sosio-kultural Islam-kristen D I Maluku, Revaldo Pravasta, Julian $\mathrm{Mb}$, Izak Yohan, and Matriks Lattu. "Jurnal Antropologi: Isu-Isu Sosial Budaya |" 1, no. June (2020): 70-80.

Kahmad, Dadang. Sosiologi Agama. Bandung: Rosdakarya, 2000.

Maluku, Kisah-kisah Perdamaian. Carita Orang Basudara, n.d.

Margawati, Margaretha. "Konflik Antara Agama Atau Politisasi Agama." Prosiding 
Simposium Internasional Jurnal Antropologi Indonesia 1 (2000): 513-17.

Olifia, Sandra, and Radita Gora. "Membangun Paradigma Komunikasi Dalam Perspektif Habermas.” Jurnal Ikom Usni Vol. 5 No. (2017): 66-86.

Pattiasina, Sharon Michelle O, and Izak Y M Lattu. "PEREMPUAN DAN PERDAMAIAN Hubungan Islam-Kristen Dalam Liminalitas Simbolik Kain Gandong Di Maluku” 11, no. 2 (2018): 205-32.

Scumman, Olaf. Some Reflection on The Meaning and Aims of Interfaith Dialogue in Dialogue and Beyond: Christians and Muslims, Together on the Way. Switzerland: The Luteran World Moderation, 2003.

Setyawan, Yusak B. "Encountering State Ideology: Reading the Bible from an Indonesian Postcolonial Perspective.” In Colonial Contexts and Postcolonial Theologies: Storyweaving in the Asia-Pasific. New York: Palgrave Macmillan, 2014.

Suseno, Frans Magnis. Pijar-Pijar Filsafat. Yogyakarta: Kanisius, 2005.

Takdir, Mohammad. "Model-Model Kerukunan Umat Beragama Berbasis Local Wisdom: Potret Harmonisasi Kebhinekaan Di Nusa Tenggara Timur.” Tapis 1 (2017): 61-83.

Thomas, Frans. "Wacana Tradisi Pela Dalam Masyarakat Ambon.” Bahasa Dan Seni 38 (2010): 166-80.

Wakano, Abidin. "Nilai-Nilai Pendidikan Multikultural Dalam Kearifan Lokal Masyarakat Maluku." Pendidikan Agama Islam 4 (2019): 26-43.

Watloly, A. Menggali Sejarah Dan Kearifan Lokal Maluku. Jakarta: Cahaya Pineleng, 2012. 